\title{
In vitro propagation and acclimatization of genipapo accessions
}

\author{
Propagação in vitro e aclimatização de acessos de jenipapeiro
}

\author{
Francielen Paola de Sa ${ }^{1}$, Ana da Silva Ledo2*, Julie Anne Espindola Amorim", \\ Ana Veruska Cruz da Silva², Moacir Pasqual ${ }^{3}$
}

\author{
'Universidade Federal de Sergipe/UFS, Probiotec, São Cristóvão, SE, Brasil \\ Empresa Brasileira de Pesquisa Agropecuária/Embrapa, Tabuleiros Costeiros, Aracajú, SE, Brasil \\ ${ }^{3}$ Universidade Federal de Lavras/UFLA, Departamento de Agricultura/DAG, Lavras, MG, Brasil \\ *Corresponding author: ana.ledo@embrapa.br \\ Received in october 5, 2015 and approved in february 15, 2016
}

\begin{abstract}
Genipapo is a species with an intermediate seed storage behavior, and its germination is slow and asynchronous; therefore the tissue culture is an alternative strategy for the propagation in large-scale. This study aimed to evaluate three genipapo accessions at different micropropagation stages (adventitious shoot induction, in vitro rooting and acclimatization). Genipapo nodal segments from the Sabinópolis (AS), Cruz das Almas (CZA) and Núcleo Bandeirante (NB) accessions were used and inoculated in culture media with 0 and 1.0 mg L-1 6-benzylaminopurine (BAP). Different indole-3-butyric acid (IBA) concentrations were tested for in vitro rooting. Subsequently, the effect of two substrates on the seedling development of three genipapo accessions was assessed. The molecular characterization of accessions was performed using 15 inter-simple sequence repeat (ISSR) primers, and genotype clustering was performed based on genetic dissimilarity using the Unweighted Pair-Group Method with Arithmetic Mean (UPGMA). Culture media supplementation with $1.0 \mathrm{mg} \mathrm{L}^{-1}$ BAP favors the development of adventitious shoots and promotes a higher callogenesis percentage, leaf number and feasibility at 90 days of in vitro culture. The immersion of the basal portion of shoots for 20 seconds in all IBA solutions induces the rhizogenesis in the genipapo accessions at 90 days of in vitro culture. The substrates consisting of washed sand + dried coconut shell powder, at a 1:1 ratio by volume, and Topstrato HT® may be recommended for genipapo acclimatization. The NB accession is genetically different from the CZA and AS populations and shows superiority for most of the variables analyzed.
\end{abstract}

Index terms: Genipa americana; in vitro culture; micropropagation.

\section{RESUMO}

O Jenipapeiro é uma espécie com comportamento intermediário para o armazenamento de sementes e sua germinação é lenta e com baixa uniformidade. A cultura de tecidos é uma estratégia alternativa para a sua propagação em larga escala. O objetivo deste trabalho foi avaliar três acessos de jenipapeiro em diferentes etapas da micropropagação (indução de brotações adventícias, enraizamento in vitro e aclimatização). Foram utilizados segmentos nodais de jenipapeiro dos acessos AS (Sabinópolis), CZA (Cruz das Almas) e NB (Núcleo Bandeirante), inoculados em meio de cultura na presença de 0 e $1 \mathrm{mg} \mathrm{L}^{-1}$ de BAP. Para o enraizamento in vitro foram testadas diferentes concentrações de AIB. Posteriormente, verificou-se o efeito de dois substratos na aclimatização. A caracterização molecular dos acessos foi realizada utilizando 15 iniciadores ISSR e o agrupamento dos genótipos foi com base na dissimilaridade genética pelo método UPGMA. A adição de $1 \mathrm{mg} \mathrm{L}^{-1}$ de BAP favorece o desenvolvimento de brotações adventícias e promove maior porcentagem de calogênese, número de folhas e viabilidade aos 90 dias de cultivo in vitro. Todas as concentrações avaliadas de AlB induzem rizogênese em mudas micropropagadas de jenipapeiro. Os substratos compostos de areia lavada + po da casca do coco seco, na proporção 1:1, e Topstrato HT podem ser recomendados para aclimatização dos acessos. O acesso NB é geneticamente distinto das populações de CZA e AS e, apresenta superioridade para a maioria das variáveis analisadas.

Termos para indexação: Genipa americana; cultura in vitro; micropropagação.

\section{INTRODUCTION}

The family Rubiaceae is composed of 550 genera and approximately 9,000 species (Judd et al., 2008). The genus Genipa has only two species: G. americana L. and G. infundibuliformis Zappi \& Semir; the former species is native and grown throughout the Neotropical region, from Mexico to Patagonia, and the latter is only found in South-Central Brazil (Delprete; Smith; Klein,
2005). Given its abundant seed production, hardiness, adaptability and production of fruits attractive to animals, $G$. americana may be used in revegetation programs for conservation areas and for the recovery of degraded areas (Vieira; Gusmão, 2006). This species has great demand by the fresh fruit market because it produces a very tasty fruit with low perishability and excellent nutritional qualities (Dantas et al., 2009). 
Genipapo show intermediate seed storage behaviour, and its germination is slow and asynchronous (Ferreira et al., 2007), which hinders seed propagation. Thus, tissue culture is an alternative strategy for the large-scale, shortterm propagation of healthy seedlings, regardless of season (Soares et al., 2007; Pinhal et al., 2011).

Different performances between genotypes of a given species may be observed during in vitro culture, that is, specimens from a given plant species may show variation in their ability to regenerate seedlings, a phenomenon termed genotype-dependence (Azevedo; Houllou-Kido; Isepoon, 2007). Variation on among genipapo genotypes behavior was observed when studying the effect of growth regulators on the induction of adventitious shoots (Rocha et al., 2008; Yee; Goh; Rao, 2010; Almeida et al., 2015). These results evidence the importance of studying different genotypes to individually evaluate the response on the in vitro culture and in the acclimatization phase for the high performance on propagation protocols.

This study aimed to evaluate the performance of three genipapo accessions at different micropropagation stages (adventitious shoot induction, in vitro rooting and acclimatization), to define the growth regulator concentration for each stage and optimal substrate in the seedling acclimatization.

\section{MATERIAL AND METHODS}

The seeds were extracted from mature fruits and then immediately washed in water and dried at room temperature by 24 hours. The mature fruits were obtained from natural populations from Sabinópolis, Siriri, Sergipe (accession AS10³6'50.79'S; 3707'36.05" W), Cruz das Almas, Bahia (accession CZA 12\%39'11''S; $39^{\circ}$ 07'19.02'W), and Núcleo Bandeirante, Federal District (accession NB 15'51'55.72's; 4757'34.59'”W).

The seeds were submitted to sterilization process in a laminar flow cabinet by immersion in $70 \%(\mathrm{v} / \mathrm{v})$ ethanol for 60 seconds, followed by 20 minutes in $2.5 \%$ sodium hypochlorite $(\mathrm{NaOCl})$ containing two drops of Tween 20. After that, were rinsed three times with sterile distilled water to remove minor amounts of disinfection liquid and inoculated in MS (Murashige; Skoog, 1962) culture medium supplemented with $0.3 \%(\mathrm{w} / \mathrm{v})$ sucrose and gelled, 0.4\% (w/v) Phytagel ${ }^{\circledR}$.

After two months of in vitro culture, nodal segments were excised and inoculated in $250 \mathrm{~mL}$ flasks with $30 \mathrm{~mL}$ of MS medium, supplemented with 0 and $1.0 \mathrm{mg} \mathrm{L}^{-1}$ 6-benzylaminopurine (BAP) and $30 \mathrm{~g} \mathrm{~L}^{-1}$ sucrose, and sealed with a plastic cap to induce the multiplication of adventitious shoots in the three different accessions. The percentage of callogenesis, percentage of shoot formation, number of adventitious shoots per nodal segment and the number of leaves per shoot were assessed at days 30, 60 and 90.

To induce rooting, the basal portion of adventitious shoots were immersed in 3-indolebutyric acid (IBA) solutions at concentrations of $0,400,600$ and 800 $\mathrm{mg} \mathrm{L}^{-1}$ for twenty seconds and were inoculated in test tubes $(20 \times 150 \mathrm{~mm})$ containing $20 \mathrm{~mL}$ of MS medium supplemented with $0.3 \%(\mathrm{w} / \mathrm{v})$ sucrose and gelled, $0.4 \%$ $(\mathrm{w} / \mathrm{v})$ Phytagel $^{\circledR}$. The percentage of rooting, percentage of callogenesis, shoot and main root length, leaf number and viability were assessed at days 30, 60 and 90 of in vitro culture. The viability was evaluated according to a grading scale from 1 to 5, where 1 represents completely dead leaves and buds; grade 2: more than 50\% desiccation and death of leaves and buds; grade 3: 30 to 50\% desiccation and death of leaves and buds; grade 4: beginning of desiccation and death of leaves, and grade 5: completely green leaves and buds (Lemos et al., 2002 adapted by Almeida et al., 2015).

Following the in vitro rooting, the seedlings were removed from the culture flasks, washed in sterile distilled water to remove the culture media residue and transferred to plastic cups $(300 \mathrm{~mL})$ with two types of substrates: $\mathrm{S} 1$, consisting of washed sand + dried coconut shell powder, at a 1:1 ratio in volume, and $\mathrm{S} 2$, the commercial substrate Topstrato $^{\circledR}$ HT Hortaliças. Both of the substrates were previously sterilized in an autoclave at $121^{\circ} \mathrm{C}$, under 1.05 $\mathrm{kg} \mathrm{cm}{ }^{-2}$ pressure, for 20 minutes. The plants remained in a growth room for 15 days at a temperature of $26 \pm 2{ }^{\circ} \mathrm{C}$, relative humidity of $70 \%$, under a 12 -hour photoperiod with approximately $38 \mu \mathrm{mol} \mathrm{s} \mathrm{s}^{-1} \mathrm{~m}^{-2}$ photon lux, with daily watering and weekly applications of $50 \mathrm{~mL}$ liquid MS per recipient. Then, the plants were transferred to a greenhouse. The following parameters were evaluated at day 60: shoot length, considering the length from the substrate level to the leaf apex in the apical portion; the number of nodal segments, adventitious shoots and leaves developed; and viability.

A completely randomized factorial design $3 \times 2$ (three accessions combined with two BAP concentrations) with four replicates, comprising one shoot per experimental unit, was applied to induce adventitious shoots. A completely randomized design $3 \times 4$ (three accessions combined with four IBA concentrations) with four replicates, composed of one shoot per experimental unit, was used for the rhizogenesis phase. The acclimatization experiment was conducted according to a completely randomized factorial design $3 \times 4 \times 2$ factorial arrangement (three accessions, four IBA concentrations and two substrates), totaling 24 treatments with two replicates 
and one plant per experimental unit. The data from the variables of all of the experiments were submitted to analysis of variance using the F-test and compared using Tukey's test at $5 \%$ significance. In addition, polynomial regression equations were fitted for the quantitative treatments. All of the analyses were carried out using the statistical software SISVAR (Ferreira, 2011).

For the molecular analysis, young leaves were collected from ten seedlings of each accession germinated in vitro. The material was placed in properly labeled paper envelopes and transported in coolers with ice to the molecular biology laboratory where they were stored in a freezer at $-80^{\circ} \mathrm{C}$.

The DNA of young leaves from each specimen was extracted according to the method by Doyle and Doyle
(1991) using the Unweighted Pair Group Method with Arithmetic Mean (UPGMA) to cluster the genotypes based on genetic dissimilarity. The genetic distance estimated using the Jaccard coefficient was used to construct a dendrogram using Numerical Taxonomy and Multivariate Analysis System (NTSYS) software. The dendrogram cut off point was defined by the first branch point.

\section{RESULTS AND DISCUSSION}

There was a significant effect of interaction between accessions and BAP concentrations on the percentage of callogenesis, number of adventitious shoots and number of leaves in the multiplication phase at 30,60 and 90 days (Table 1). No significant differences were found between treatments regarding the percentage of shoot formation.

Table 1: Percentage of callogenesis, percentage of shoot formation, number of leaves per adventitious shoot, number of adventitious shoot per nodal segment of genipapo accessions at 30,60 and 90 days of in vitro culture.

\begin{tabular}{|c|c|c|c|c|c|c|}
\hline \multirow{3}{*}{ Accessions } & \multicolumn{2}{|c|}{30 days } & \multicolumn{2}{|c|}{60 days } & \multicolumn{2}{|c|}{90 days } \\
\hline & \multicolumn{6}{|c|}{$\operatorname{BAP}\left(\mathrm{mg} \mathrm{L}^{-1}\right)$} \\
\hline & 0 & 1 & 0 & 1 & 0 & 1 \\
\hline & \multicolumn{6}{|c|}{ Callogenesis (\%) } \\
\hline AS & $0.0 \mathrm{bB}$ & $6.9 \mathrm{aB}$ & $4.7 \mathrm{bB}$ & $65.0 \mathrm{aB}$ & $11.5 \mathrm{bA}$ & $85.0 \mathrm{aB}$ \\
\hline CZA & $0.0 \mathrm{bB}$ & $85.0 \mathrm{aA}$ & $1.4 \mathrm{bA}$ & $90.0 \mathrm{aA}$ & $2.8 \mathrm{bA}$ & $97.5 \mathrm{aA}$ \\
\hline NB & $0.5 \mathrm{bA}$ & $3.6 \mathrm{aB}$ & $0.5 \mathrm{bA}$ & $12.2 \mathrm{aC}$ & $0.6 \mathrm{bA}$ & $14.0 \mathrm{aC}$ \\
\hline \multirow[t]{2}{*}{ VC(\%) } & \multicolumn{2}{|c|}{33.08} & \multicolumn{2}{|c|}{42.37} & \multicolumn{2}{|c|}{26.13} \\
\hline & \multicolumn{6}{|c|}{ Shoot formation (\%) } \\
\hline AS & $100 \mathrm{aA}$ & $100 \mathrm{aA}$ & $100 \mathrm{aA}$ & $100 \mathrm{aA}$ & $100 \mathrm{aA}$ & $100 \mathrm{aA}$ \\
\hline CZA & $66.7 \mathrm{aA}$ & $100 \mathrm{aA}$ & $77.7 \mathrm{aA}$ & $100 \mathrm{aA}$ & $100 \mathrm{aA}$ & 100 a $A$ \\
\hline NB & $100 \mathrm{aA}$ & $100 \mathrm{aA}$ & $100 \mathrm{aA}$ & $100 \mathrm{aA}$ & $100 \mathrm{aA}$ & $100 \mathrm{aA}$ \\
\hline \multirow[t]{2}{*}{ VC(\%) } & \multicolumn{2}{|c|}{20.90} & \multicolumn{2}{|c|}{18.10} & \multicolumn{2}{|c|}{18.10} \\
\hline & \multicolumn{6}{|c|}{ Number of leaves } \\
\hline AS & $3.6 \mathrm{bA}$ & $7.6 \mathrm{aA}$ & $5.3 \mathrm{bA}$ & $11.1 \mathrm{aB}$ & $2.5 \mathrm{bB}$ & $11.2 \mathrm{aB}$ \\
\hline CZA & $1.0 \mathrm{bB}$ & $6.9 \mathrm{aA}$ & $1.8 \mathrm{bB}$ & $9.2 \mathrm{aC}$ & $6.0 \mathrm{bA}$ & $12.0 \mathrm{aB}$ \\
\hline NB & $3.3 \mathrm{bA}$ & $8.7 \mathrm{aA}$ & $5.3 \mathrm{bA}$ & $16.8 \mathrm{aA}$ & $6.4 \mathrm{bA}$ & $19.3 \mathrm{aA}$ \\
\hline \multirow[t]{2}{*}{$\mathrm{VC}(\%)$} & \multicolumn{2}{|c|}{14.20} & \multicolumn{2}{|c|}{8.30} & \multicolumn{2}{|c|}{8.72} \\
\hline & \multicolumn{6}{|c|}{ Number of adventitious shoot } \\
\hline AS & $0.4 \mathrm{bB}$ & $1.6 \mathrm{aA}$ & $0.6 \mathrm{bB}$ & $1.7 \mathrm{aB}$ & $1.0 \mathrm{bB}$ & $1.7 \mathrm{aB}$ \\
\hline CZA & $0.4 \mathrm{bB}$ & $1.7 \mathrm{aA}$ & $1.0 \mathrm{bA}$ & $1.7 \mathrm{aB}$ & $1.1 \mathrm{bA}$ & $1.8 \mathrm{aB}$ \\
\hline NB & $1.0 \mathrm{bB}$ & $1.9 \mathrm{aA}$ & $1.1 \mathrm{bA}$ & $2.1 \mathrm{aA}$ & $1.2 \mathrm{bA}$ & $2.4 \mathrm{aA}$ \\
\hline VC(\%) & \multicolumn{2}{|c|}{11.49} & \multicolumn{2}{|c|}{8.57} & \multicolumn{2}{|c|}{6.97} \\
\hline
\end{tabular}

Means followed by the same lowercase letter in rows and the same uppercase letter in columns are not different from each other according to Tukey's test at a 5\% probability. VC = Variation Coefficient. 
The CZA accession showed greater formation of callogenesis $(97.5 \%)$ in the presence of BAP, in contrast to the NB accession, with $14 \%$ at 90 days.

The NB accession showed the greatest number of adventitious shoots per nodal segment (2.4) at 90 days of culture in the presence of $1.0 \mathrm{mg} \mathrm{L}^{-1} \mathrm{BAP}$. NB was followed by the CZA (1.8) and AS (1.7) accessions, with no significant differences between those two. Genetic control of plant regeneration has been observed in several plant species and exploited in some cases to improve plant materials for use in tissue culture research (Rokhshana Khatun; Shahinul; Bari Miah, 2010). Therefore, different responses are observed among genotypes of a given species. The induction of adventitious shoots occurred even in the absence of growth regulator, although superior results were observed in the presence of BAP. Similar results were recorded in stem apices of Illex paraguariensis (Horbach et al., 2011) and in stem segments of Hancornia speciosa (Soares et al., 2011). There was no increase in the number of shoots of the AS accession in the presence of BAP between the last two assessments (60 and 90 days), whereas the NB and CZA accessions showed a mean increase of only 0.3 and 0.1 , respectively, suggesting the use of an interval of 30 days or a maximum interval of 60 days for subcultures.

The NB accession showed greater formation of leaves (19.3) at 90 days of culture in the presence of BAP. Similar results were observed in blackberry plants, with maximum leaf development (7.89) in the presence of $1.0 \mathrm{mg} \mathrm{L}^{-1} \mathrm{BAP}$ (Villa et al., 2005), and in Dendrobium nobile seedlings, with the greatest number of leaves (5.47) in the presence of $2.7 \mathrm{mg} \mathrm{L}^{-1}$ BAP (Soares et al., 2011). These results disagree with those recorded in nodal segments of Lipia alba, where the greatest number of leaves was observed in the absence of BAP (Asmar et al., 2012). According to the authors, this cytokinin promotes a greater number of small-sized buds, showing a smaller number of nodal segments and leaves, an effect that was not observed in this study.

A positive effect of culture media supplementation with BAP occurred for the mean length of adventitious shoots. A greater length was observed in the NB accession $(3.45 \mathrm{~cm})$, and no significant differences occurred between the accessions AS $(2.35 \mathrm{~cm})$ and CZA $(2.50 \mathrm{~cm})$, data not shown. However, the explants showed similar heights that were lower than $1.53 \mathrm{~cm}$ in the absence of BAP in the culture media. Cytokinins are a class of plant-growth regulators able to induce cell division (Nishimura et al., 2004) and are responsible for the formation of organs, especially plant shoot organs (Moura et al., 2012).The superiority of the cultures maintained in the presence of $1.0 \mathrm{mg} \mathrm{L}^{-1} \mathrm{BAP}$ is evidenced by greater leaf number, adventitious shoots and shoot length when compared with those of the plants grown in the absence of cytokinin.

Species exhibit variable performance in response to supplementation with BAP as a result of the endogenous hormonal balance or the type of explant used. Endogenous cytokinin may interact with the BAP supplemented into the culture media, thus affecting the explant response (George; Hall; De Klerk, 2008a). Furthermore, the different performances observed between genipapo accessions may be attributed to genetic factors. Genetic differences may be observed during in vitro culture and plant regeneration. Borges et al. (2011) report the variability of responses among genotypes during in vitro multiplication, with some clones easily adapting to the in vitro conditions but others requiring adjustments to the culture media.

In the in vitro rooting phase, there was an isolated significant effect of accessions and IBA concentration on the root and shoot length and leaf number and a significant effect of the interaction between IBA and accessions for the percentage of calluses and viability. Although no significant differences were detected, all of the IBA concentrations induced rhizogenesis in adventitious shoots, and the treatment with $600 \mathrm{mg} \mathrm{L}^{-1}$ provided the greatest rooting percentage $(100 \%)$, while the smallest $(88.89 \%)$ was observed in the absence of growth regulator. The CZA accession reached $100 \%$ rooting, followed by NB (93.75\%) and AS (89.58\%). Rocha et al. (2008) observed a maximum of $83 \%$ in vitro rooting of adventitious shoots in the JRB59 and JRB69 accessions of Genipa americana.

The superiority of NB accession was noted in regard to shoot length, which reached $6.06 \mathrm{~cm}$ on average, while the smallest length $(2.45 \mathrm{~cm})$ was observed in accession AS (Figure 1). The greatest value of root length observed was $8.28 \mathrm{~cm}$ in the accession CZA, and the smallest, $6.50 \mathrm{~cm}$, was observed in NB, which was not significantly different from AS. Those results were larger than those found by Rocha et al. (2008), who recorded a maximum length of $3.65 \mathrm{~cm}$ in genipapo accessions at 60 days of acclimatization in the presence of $3.3 \mathrm{mg} \mathrm{L}^{-1} \mathrm{IBA}$, a lower concentration than those used in the present study.

Means followed by the same letter are not significantly different from each other according to Tukey's test at $5 \%$ probability.

Considering the effect of accessions on the leaf number, 14.42 leaves were observed for the NB accession, followed by AS (11.26) and CZA (10.40). Reports show that the presence of leaves is a key factor in the rooting of cuttings (Vignolo et al., 2014), and the presence of leaves is an excellent indicator of the rooting capacity of cuttings. 


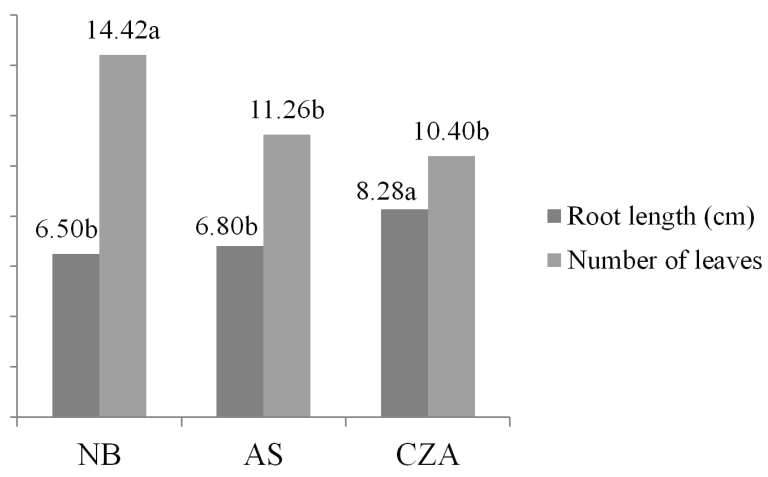

Figure 1: Root length $(\mathrm{cm})$ and number of leaves per adventitious shoots of three genipapo accessions in the presence of IBA at 90 days of in vitro culture.

Although the IBA concentration effect was significant, a regression model with biological meaning for root length could not be established, which reached $6.8 \mathrm{~cm}$ in length in the absence of IBA. Rocha et al. (2008) noted that the absence of IBA in the rooting media precluded the formation of roots in genipapo accessions JRB59 and JRB69. In vitro adventitious rooting is genotype dependent. Thus, different species and hybrids and clones of the same species may require different culture conditions (Mokodeti et al., 2003; Cunha et al., 2009).

The absence of auxin from the culture media resulted in the greatest leaf number (13.8), and the increase in IBA concentration promoted a decrease in leaf number, following a linear regression (Figure 2).

No calluses were formed in adventitious shoots cultured in the absence of IBA, although concentrations higher than $400 \mathrm{mg} \mathrm{L}^{-1}$ IBA induced the presence of calluses on the basal portion of the explants.

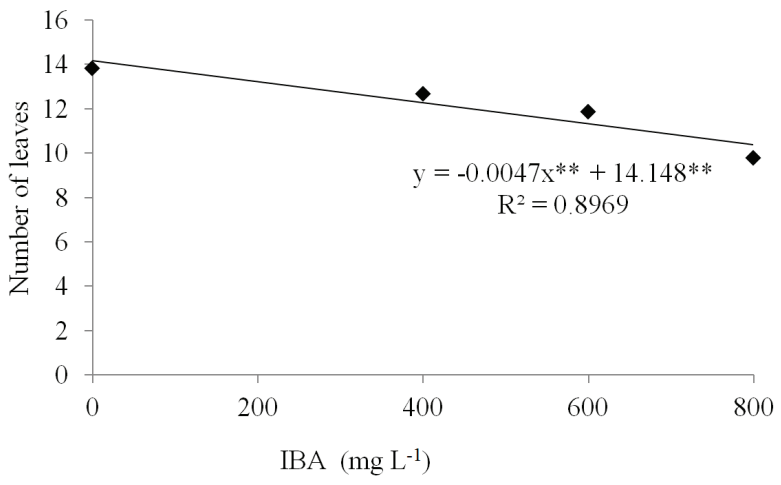

Figure 2: Leaf number of genipapo adventitious shoots at different IBA concentrations at 90 days of in vitro culture.
An increasing trend in the percentage of callus formation in axillary buds of black sucupira (Bowdichia virgilioides Kunth.) with an increase in IBA concentration were observed by Moura et al. (2012). The presence of callus in the rooting area may affect the root quality, especially regarding the vascular connection with the plant (George; Hall; De Klerk, 2008b). This effect was not confirmed in the present study because approximately 95\% rooting was observed. Furthermore, CZA accession showed $100 \%$ callogenesis, $100 \%$ rooting and greatest root length $(8.28 \mathrm{~cm})$.

Significant effects of the interaction between accession and substrate (Table 2) and the interaction between accession and IBA concentration (Table 3) occurred for all of the variables analyzed.

The highest survival rates occurred in NB in both of the substrates, and all of the plants of that accession grown in S2 survived. A contrasting result was recorded with AS accession, where in S2 provided the lowest survival rate $(20 \%)$. Again, different performances were detected between accessions even when the accessions were subjected to identical environmental and nutritional conditions, which indicate the importance of defining specific protocols for each genotype.

In tests using the substrates Ecoterra ${ }^{\circledR}$, Plantmax ${ }^{\circledR} \mathrm{HT}$ and washed sand in the acclimatization of genipapo genotypes JRB 59 and JRB 69, Rocha et al. (2008) observed that accession JRB 69 acclimatized in Ecoterra ${ }^{\circledR}$ substrate exhibited the highest survival rate $(50 \%)$, whereas the lowest survival rate was found in JRB59 grown with washed sand.

The plants of accessions AS and NB showed the greatest heights (1.75 and $2.56 \mathrm{~cm}$, respectively) when grown in substrate $\mathrm{S} 1$, although $\mathrm{S} 2$ provided the greatest length $(2.12 \mathrm{~cm})$ of accession CZA. Furthermore, S2 promoted the greatest number of nodal segments (5.46) in $\mathrm{NB}$, unlike what occurred in AS, wherein the highest value recorded (2.58) occurred in S1. The highest value of leaf number was recorded in NB accession (2.80), followed by AS (2.02), both grown in substrate $\mathrm{S} 2$, and in CZA (1.75) grown in S1. Regarding viability, NB and CZA accessions, both grown in S2, exhibited similar scores of 3.77 and 3.71 , respectively.

A significant effect of the interaction between accession and IBA on survival was observed at 60 days of acclimatization (Table 3). The adventitious shoots of ns CZA and NB accessions treated with the concentrations of 400 and $600 \mathrm{mg} \mathrm{L}^{-1}$ IBA in the in vitro phase showed the highest survival rate in acclimatization (100\%). The AS accession showed overall survival rates lower than $50 \%$, 
except for the shoots treated with $800 \mathrm{mg} \mathrm{L}^{-1} \mathrm{IBA}$, which displayed $83.30 \%$ survival. The NB accession presented the best performance regarding shoot length $(9.26$ and $10.19 \mathrm{~cm}$ ), number of nodal segments (5.50 and 5.99), and leaf number (9.78 and 7.04) in the presence of 400 and $600 \mathrm{mg} \mathrm{L}^{-1} \mathrm{IBA}$, respectively. The superiority of NB accession may be explained by the fact that the in vitro cultures were more vigorous, providing greater adaptation in the acclimatization phase.
Plants are photosynthetically inactive and poorly lignified, with slightly thickened cells, abundant intercellular spaces and undeveloped vascular systems, during in vitro culture (Santana et al., 2008). Physiological and morphological adaptations must occur during the acclimatization phase to ensure greater survival (Lédo et al., 2007). The plants of accessions AS and CZA showed the worst performance, and further studies improving the conditions of in vitro culture and acclimatization are necessary.

Table 2: Survival, shoot length, number of nodal segments per plant, number of leaves per plant and viability of genipapo accessions according to two substrates at 60 days of acclimatization.

\begin{tabular}{|c|c|c|}
\hline \multirow{2}{*}{ Accessions } & \multicolumn{2}{|c|}{ Substrates } \\
\hline & S1 & S2 \\
\hline \multicolumn{3}{|c|}{ Survival (\%) } \\
\hline AS & $73.3 \mathrm{aAB}$ & $20.0 \mathrm{bB}$ \\
\hline CZA & 46.2 bB & $78.6 \mathrm{aA}$ \\
\hline NB & $81.3 \mathrm{aA}$ & $100.0 \mathrm{aA}$ \\
\hline \multicolumn{3}{|c|}{ VC (\%) 52.97} \\
\hline \multicolumn{3}{|c|}{ Shoot length (cm) } \\
\hline AS & $1.75 \mathrm{aB}$ & $0.92 \mathrm{bC}$ \\
\hline CZA & 1.43 bB & $2.12 \mathrm{aB}$ \\
\hline NB & $2.56 \mathrm{aA}$ & $3.03 \mathrm{aA}$ \\
\hline \multicolumn{3}{|c|}{ VC (\%) 35.89} \\
\hline \multicolumn{3}{|c|}{ Number of nodal segments } \\
\hline AS & $2.58 \mathrm{aAB}$ & $0.70 \mathrm{bB}$ \\
\hline CZA & $1.88 \mathrm{aB}$ & $2.46 \mathrm{aB}$ \\
\hline NB & $4.38 \mathrm{aA}$ & $5.46 \mathrm{aA}$ \\
\hline \multicolumn{3}{|c|}{ VC (\%) 37.87} \\
\hline \multicolumn{3}{|c|}{ Number of leaves } \\
\hline AS & $2.02 \mathrm{aAB}$ & $1.07 \mathrm{bB}$ \\
\hline CZA & $1.58 \mathrm{aB}$ & $1.75 \mathrm{aB}$ \\
\hline NB & $2.39 \mathrm{aA}$ & $2.80 \mathrm{aA}$ \\
\hline \multicolumn{3}{|c|}{ VC (\%) 39.23} \\
\hline \multicolumn{3}{|c|}{ Viability } \\
\hline AS & $2.47 \mathrm{aA}$ & $0.90 \mathrm{bB}$ \\
\hline CZA & $2.15 \mathrm{bA}$ & $3.71 \mathrm{aA}$ \\
\hline NB & $3.38 \mathrm{aA}$ & $3.77 \mathrm{aA}$ \\
\hline
\end{tabular}

S1 - consisting of washed sand + dried coconut shell powder, in a 1:1 ratio by volume, and S2 - commercial substrate Topstrato HT Hortaliças. VC= Variation Coefficient. Viability = scale from 1 to 5.

Means followed by the same lowercase letter in rows and the same uppercase letter in columns are not different from each other according to Tukey's test at a 5\% probability. 
Table 3: Survival, shoot length, number of nodal segments per plant, number of leaves per plant and viability of genipapo accessions at 60 days of acclimatization according to the IBA concentration on the in vitro phase.

\begin{tabular}{|c|c|c|c|c|}
\hline \multirow{2}{*}{ Accessions } & \multicolumn{4}{|c|}{ IBA $\left(\mathrm{mg} \mathrm{L}^{-1}\right)$} \\
\hline & 0 & 400 & 600 & 800 \\
\hline & \multicolumn{4}{|c|}{ Survival (\%) } \\
\hline AS & $40.00 \mathrm{Aa}$ & $42.90 \mathrm{Ba}$ & $42.90 \mathrm{Ba}$ & $83.30 \mathrm{Aa}$ \\
\hline CZA & $50.00 \mathrm{Aab}$ & $62.50 \mathrm{ABa}$ & $100.00 \mathrm{Aa}$ & $28.60 \mathrm{Bb}$ \\
\hline NB & $71.40 \mathrm{Aa}$ & $100.00 \mathrm{Aa}$ & $100.00 \mathrm{Aa}$ & $87.50 \mathrm{Aa}$ \\
\hline \multicolumn{5}{|c|}{ VC (\%) 45.74} \\
\hline & \multicolumn{4}{|c|}{ Shoot length (cm) } \\
\hline AS & 1.37 Aa & $1.91 \mathrm{Ba}$ & $1.34 \mathrm{Ca}$ & $1.86 \mathrm{Ba}$ \\
\hline CZA & $2.75 \mathrm{Ab}$ & $2.38 \mathrm{Bb}$ & $6.46 \mathrm{Ba}$ & 3.77 ABab \\
\hline NB & $5.21 \mathrm{Aa}$ & $9.67 \mathrm{Aa}$ & 10.19 Aa & $6.81 \mathrm{Aa}$ \\
\hline \multicolumn{5}{|c|}{ VC (\%) 35.89} \\
\hline & \multicolumn{4}{|c|}{ Number of nodal segments } \\
\hline AS & $1.03 \mathrm{Aa}$ & 1.87 Ba & $1.43 \mathrm{Ba}$ & 2.92 ABa \\
\hline CZA & $3.00 \mathrm{Aa}$ & $1.88 \mathrm{Ba}$ & $3.19 \mathrm{Ba}$ & 1.14 Ba \\
\hline NB & $3.13 \mathrm{Aa}$ & $5.40 \mathrm{Aa}$ & $5.99 \mathrm{Aa}$ & $4.88 \mathrm{Aa}$ \\
\hline \multicolumn{5}{|c|}{ VC (\%) 37.87} \\
\hline & \multicolumn{4}{|c|}{ Number of leaves } \\
\hline AS & $2.03 \mathrm{Aa}$ & $2.79 \mathrm{Ba}$ & $2.00 \mathrm{Ba}$ & $5.50 \mathrm{ABa}$ \\
\hline CZA & $5.00 \mathrm{Aa}$ & $2.69 \mathrm{Bb}$ & $4.38 \mathrm{ABa}$ & $1.86 \mathrm{Bb}$ \\
\hline NB & $4.34 \mathrm{Ab}$ & $9.78 \mathrm{Aa}$ & 7.04 Aab & $5.82 \mathrm{Ab}$ \\
\hline \multicolumn{5}{|c|}{ VC (\%) 39.23} \\
\hline & \multicolumn{4}{|c|}{ Viability } \\
\hline AS & $1.20 \mathrm{Aa}$ & $1.57 \mathrm{Ba}$ & $1.57 \mathrm{Ba}$ & $3.00 \mathrm{ABa}$ \\
\hline CZA & $2.50 \mathrm{Aab}$ & $3.00 \mathrm{ABa}$ & 4.62 Aa & $1.29 \mathrm{Bb}$ \\
\hline NB & $2.36 \mathrm{Aa}$ & $4.00 \mathrm{Aa}$ & $3.94 \mathrm{Aa}$ & $3.81 \mathrm{Aa}$ \\
\hline VC(\%) 3 & & & & \\
\hline
\end{tabular}

Means followed by the same lowercase letter in rows and the same uppercase letter in columns are not different from each other according to Tukey's test at a 5\% probability. VC= Variation Coefficient. Viability = scale from 1 to 5.

The molecular characterization of accessions by polymerase chain reaction using fifteen ISSR primers enabled the generation of 49 fragments with 34 polymorphisms (69\% polymorphism). Each primer generated from one (17899B, HB13, HB14) to six (HB11, HB15) bands and the high polymorphism existing between the different accessions was evidenced in most cases. The genetic distance between specimens estimated using the Jaccard coefficient was used to construct a UPGMA dendrogram. The distribution of genotypes in the dendrogram formed two large groups (Figure 3).

The first group (G1) consisted of all of the specimens from the AS and CZA accessions and three specimens from the NB accession (NB2, NB5 and NB 7). Group 2 (G2) included the remaining specimens from the NB accession (NB1, NB8, NB6, NB4, NB3, NB9 and NB10), suggesting the existence of a difference among specimens according to their place of origin. 


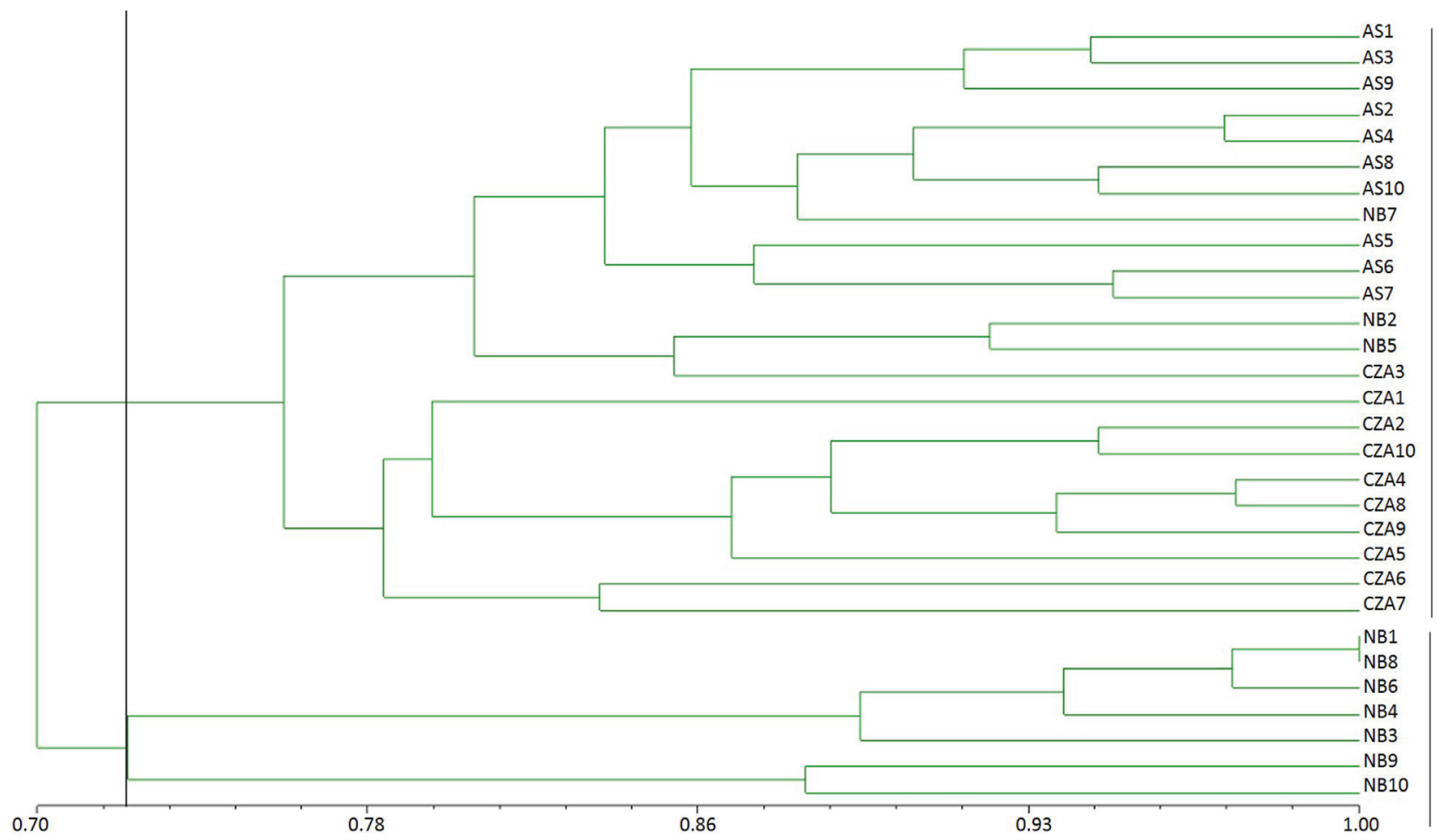

Figure 3: Dendrogram of genetic dissimilarity between genipapo accessions using ISSR markers. The dotted line indicates the cut-off point defined by the first branch point.

\section{CONCLUSIONS}

Culture media supplementation with $1.0 \mathrm{mg} \mathrm{L}^{-1} \mathrm{BAP}$ favors the development of adventitious shoots on genipapo accessions at 90 days of in vitro culture. The immersion of the basal portion of shoots for 20 seconds in all IBA solutions induces the rhizogenesis on genipapo accessions at 90 days of in vitro culture. The substrates consisting of washed sand + dried coconut shell powder, at a $1: 1$ ratio by volume, and Topstrato $\mathrm{HT}^{\circledR}$ may be recommended for genipapo acclimatization. The NB accession is genetically different from the populations of CZA and AS and shows superiority for most of the variables analyzed.

\section{ACKNOWLEDGMENTS}

The authors would like to thank Procad/Capes for granting a scholarship and CNPq/SISBIOTA (563363/2010-0), FAPITEC/SE and Embrapa for the financial resources and infrastructure.

\section{REFERENCES}

ALMEIDA, C. S. et al. Respostas morfogenéticas de jenipapeiro em diferentes condições de cultura in vitro. Revista Caatinga. 28(1):58-64, 2015.

ASMAR, S. A. et al. Concentrações de BAP sobre a proliferação in vitro de brotos de Lippia alba. Revista Brasileira de Plantas Medicinais,14:149-153, 2012.

AZEVEDO, H.; HOULLOU-KIDO, L.; ISEPOON, A. M. B. Análise do potencial regenerativo in vitro de diferentes cultivares de feijão-caupi. Revista Brasileira de Biociências, 5(2):528539, 2007.

BORGESS, R. et al. Multiplicação in vitro de clones híbridos de Eucalyptus globulus. Revista Árvore, 35(2):173-182, 2011.

CUNHA, A. C. M. C. M. et al. Papel de nutrição mineral na formação de raízes adventícias em plantas lenhosas. Pesquisa Florestal Brasileira, 58:35-47, 2009.

DANTAS, A. C. V. L. et al. Jenipapo. In: SANTOS-SEREJO, J. A. et al. Fruticultura tropical: espécies regionais e exóticas. EMBRAPA, p.275- 291, 2009. 
DELPRETE, P. G.; SMITH, L. B.; KLEIN, R. M. Rubiáceas. In: REITZ, A. R. Flora Catarinense: gêneros de H-T. Itajaí: TBG/ Smithsonian, p.345-842, 2005.

DOYLE, J. J.; DOYLE, J. L. Isolation of plant DNA from fresh tissue. Focus, 1:13-15, 1991.

FERREIRA, D. F. Sisvar: a computer statistical analysis system. Ciência e Agrotecnologia, 35(6):1039-1042, 2011.

FERREIRA, W. R. et al. Crescimento de mudas de Genipa americana L. submetidas a condições de pré-semeadura. Revista Brasileira de Biociências, 5(2):1026-1028, 2007.

GEORGE, E. F.; HALL, M. A.; DE KLERK, G. J. Plant growth regulators II: citokinins, their analogues and antagonists. In: Plant propagation by tissue culture. Dordrecht: Springer, p.205-226, 2008a.

GEORGE, E. F.; HALL, M. A.; DE KLERK, G. J. The anatomy and morphology of tissue cultured plants. In: Plant propagation by tissue culture. Dordrecht: Springer, p.465-477, 2008b.

HORBACH, M. A. et al. Micropropagação de plântulas de erva-mate obtidas e embriões zigóticos. Ciência Rural, 41(1):113-119, 2011.

JUDD, W. S. et al. Plant systematics. Sunderland: Sinauer, p.527-518, 2008.

LÉDO, A. S. et al. Cultivo in vitro de embriões zigóticos e aclimatação de plântulas de coqueiro-anão. Pesquisa Agropecuária Brasileira, 42(2):147-154, 2007.

LEMOS, E. E. P. de et al. Conservação in vitro de germoplasma de cana-de-açúcar. Pesquisa Agropecuária Brasileira, 37(10):1359-1364, 2002.

MOKOTEDI, M. et al. In vitro rooting and subsequent survival of two clones of cold-tolerant Eucalyptus grandis $\times$ E. nitens hybrid. HortScience, 35(6):1163-1165, 2003.

MOURA, L. C. et al. Micropropagação de sucupira-preta por meio de gemas axilares. Pesquisa Agropecuária Brasileira, 47(12):1691-1698, 2012.

MURASHIGE, T.; SKOOG, F. A revised medium for rapid growth and bioassays with tobacco tissue culture. Physiologia Plantarum, 15:437-497, 1962.
NISHIMURA, C. et al. Histidine kinase homologs that acts as cytokinin receptors possess overlapping functions in the regulation of shoot and root growth in Arabdopsis. The Plant Cell, 16(6):1365-1377, 2004.

PINHAL, H. F. et al. Aplicação da cultura de tecidos vegetais em fruteiras do cerrado. Ciência Rural, 41(7):1136-1142, 2011.

ROCHA, M. A. C. et al. Enraizamento in vitro e aclimatização de genótipos de jenipapeiro (Genipa americana L.). Revista Brasileira de Fruticultura, 30(3):760-774, 2008.

ROKHSHANA KHATUN, S. M.; SHAHINUL, I.; BARI MIAH, M. A. Studies on plant regeneration efficiency through in vitro micropropagation and anther culture of twenty five rice cultivars in Bangladesh. Journal of Applied Sciences Research, 6(11):1705-1711, 2010.

SANTANA, J. R. et al. Estimulo do comportamento fotoautotrófico durante o enraizamento in vitro de Annona glabra L. II. Aspectos da anatomia da folha antes da aclimatização. Ciência e Agrotecnologia, 32(2):640-644, 2008.

SOARES, F. P. et al. Organogênese direta em explantes caulinares de mangabeira (Hancornia speciosa Gomes). Ciência e Agrotecnologia, 31(4):1048-1053, 2007.

SOARES, F. P. et al. Taxa de multiplicação e efeito residual de diferentes fontes de citocininas no cultivo in vitro de Hancornia speciosa Gomes. Ciência e Agrotecnologia, 35(1):152-157, 2011.

VIGNOLO, G. K. et al. Presença de folhas no enraizamento de estacas de amoreira-preta. Ciência Rural, 44(3):467-472, 2014.

VIEIRA, F. A.; GUSMÃO, E. Efeitos de giberilinas, fungicidas e do armazenamento na germinação de sementes de Genipa americana L. (Rubiaceae). Cerne, 12(2):137-144, 2006.

VILLA, F. et al. In vitro multiplication of blackberry (Rubus sp.) Ebano in different MS medium concentrations and BAP. Ciência e Agrotecnologia, 29(3): 582-589, 2005.

YEE, T. F.; GOH, C. J.; RAO, A. N. In vitro studies on Genipa americana. Journal of Tropical Medicinal Plants, 11(1):71$88,2010$. 